Life Sciences Contribution Royal Ontario Museum

Redescription of the skull and mandible of Parksosaurus from the Late Cretaceous with comments on the family Hypsilophodontidae (Ornithischia)

P. M. Galton

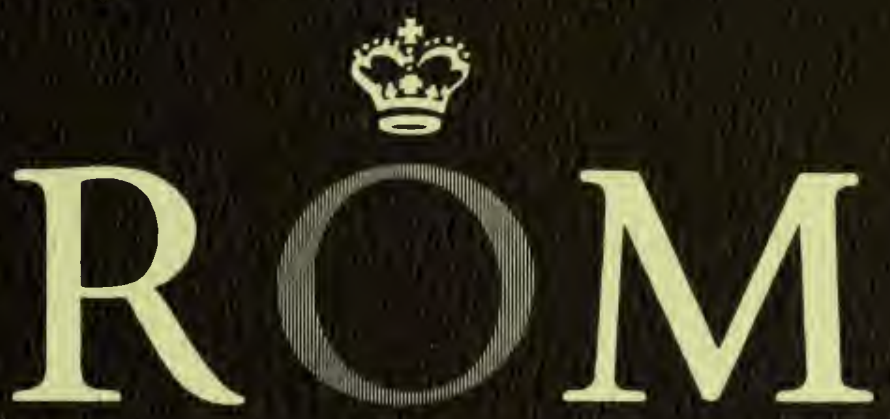


Digitized by the Internet Archive in 2011 with funding from University of Toronto 
LIFE SCIENCE CONTRIBUTIONS

ROYAL ONTARIO MUSEUM

NUMBER 89

p. m.galton Redescription of the skull and mandible of Parksosaurus

from the Late Cretaceous with comments on the family Hypsilophodontidae (Ornithischia) 


\section{ROYAL ONTARIO MUSEUM \\ PUBLICATIONS IN LIFE SCIENCES}

The Royal Ontario Museum publishes three series in the Life Sciences:

LIFE SCIENCES CONTRIBUTIONS, a numbered series of original scientific publications, including monographic works.

LIFE SCIENCES OCCASIONAL PAPERS, a numbered series of original scientific publications, primarily short and usually of taxonomic significance.

LIFE SCIENCES MISCELLANEOUS PUBLICATIONS, an unnumbered series of publications of varied subject matter and format.

All manuscripts considered for publication are subject to the scrutiny and editorial policies of the Life Sciences Editorial Board, and to review by persons outside the Museum staff who are authorities in the particular field involved.

\section{LIFE SCIENCES EDITORIAL BOARD}

Chairman: R. L. PETERSON

Editors: J.R.TAMSITT, Editor

D. B A R R, Associate Editor

E. J.CROSS MAN, Associate Editor

P. M. GaLton is an Assistant Professor of Biology at the University of Bridgeport, Bridgeport, Connecticut 06602.

PRICE : $\$ 1.50$

(C) The Royal Ontario Museum, 1973

100 Queen's Park, Toronto, Canada

PRINTED AT THE UNIVERSITY OF TORONTO PRESS 


\title{
Redescription of the skull and mandible of Parksosaurus from the Late Cretaceous with comments on the family Hypsilophodontidae (Ornithischia)
}

\begin{abstract}
The head skeleton of Parksosaurus is more similar to that of Hypsilophodon from the Lower Cretaceous of England than to those of Dryosaurus and Dysalotosaurus, two closely related genera of hypsilophodontids from the Upper Jurassic. The shallowness of the lower temporal bar is a primitive feature of the skull of Parksosaurus; specialized features include the form of the teeth, the small size of the antorbital fenestra, and the anteroposterior expansion of the posterodorsal end of the jugal. The presence of foramina for replacement teeth in several lower ornithopods represents a preadaptation for the formation of high alveolar walls necessary for the development of dental batteries in hadrosaurs and ceratopsians. The only other known hypsilophodont reported from the Late Cretaceous of the world is from British Columbia; it may represent a new species of Hypsilophodon.
\end{abstract}

\section{Introduction}

Gilmore (1913) briefly described Thescelosaurus neglectus, a new genus and species of ornithopod dinosaur from the Lance Formation of Wyoming, and referred it to the family Camptosauridae. Later (1915) he gave a more complete description and reassigned the genus to the family Hypsilophodontidae. Parks (1926) described a new species, Thescelosaurus warreni, from the Edmonton Formation of Alberta. In his description of the specimen Parks (1926) only described the left side of the skull (Fig. 1). Sternberg (1937) subsequently made $T$. warreni the generotype of Parksosaurus. Sternberg (1940, p. 492) compared characters of Thescelosaurus and Parksosaurus and stressed differences in the hind limb. In Thescelosaurus the femur is longer than the tibia, and the fourth trochanter is below midlength. In Parksosaurus the femur is shorter than the tibia, and the fourth trochanter is above midlength. Sternberg (1940) erected the subfamily Thescelosaurinae for Thescelosaurus and placed Parksosaurus in the subfamily Hypsilophodontinae. Parksosaurus was undoubtedly cursorial (see Galton, 1971a, 1971b), and I retained it in the family Hypsilophodontidiae with Pisanosaurus Casamiquela, Laosaurus Marsh, Dryosaurus Marsh, Dysalotosaurus Pompeckj, and Hypsilophodon Huxley. I did not include Thescelosaurus within the family Hypsilophodontidae but referred it to the family Iguanodontidae (Galton, 1971a, 1971b, 1972). 


\section{Material and Methods}

The crushed and distorted condition of the skull material of Parksosaurus warreni (ROM 804) warranted a series of stereo photographs with explanatory line drawings (Figs. 1-4) in addition to a reconstruction of the skull (Fig. 5). Parks (1926) described only the left side (Fig. 1) of the skull. But the right side of the specimen (Figs. 2-4) has been extensively prepared since 1926, and I recognized several elements not described by Parks when I compared this side with the disarticulated bones from a nearly complete skull of Hypsilophodon foxii Huxley (Figs. 6-8). References here to Hypsilophodon are based on material in the British Museum (Natural History), a complete account of which will appear elsewhere (Galton, in press, Br. Mus.). Specimens examined are in the collections of the following institutions: American Museum of Natural History, New York (AMNH); British Museum (Natural History), London (BMNH); Carnegie Museum, Pittsburgh (CM); National Museum of Canada, Ottawa (NMC); Royal Ontario Museum, Toronto (ROM); University of California Museum of Paleontology, Berkeley (UCMP); and Yale University Peabody Museum of Natural History, New Haven (YPM). Radiographs of the skull were made with a General Electric DXS 350 x-ray machine with an HDN tube (General Electric, Toronto, Ontario).

Abbreviations used in the figures and descriptive portions of the text are listed below. Abbreviations for the names of bones are given in upper case, those for structures in lower case, and foramina for cranial nerves are indicated by Roman numerals.

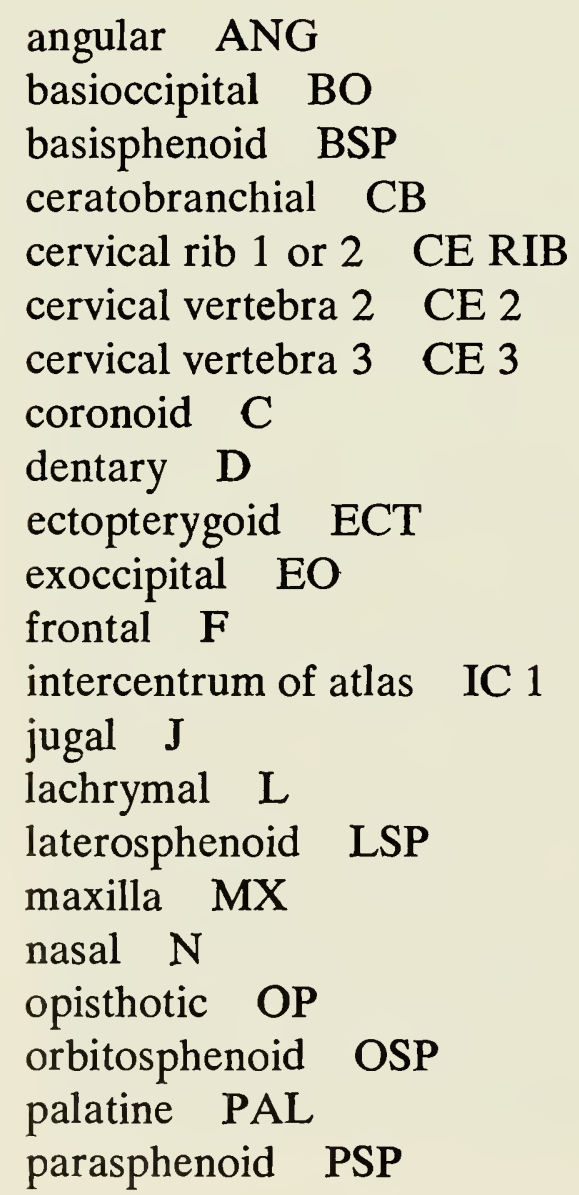

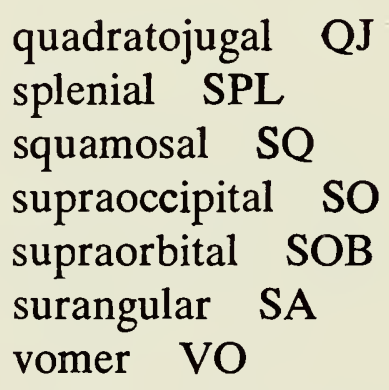




\author{
parietal $\mathbf{P}$ \\ postorbital PO \\ prearticular PA \\ predentary PD \\ prefrontal $P F$ \\ premaxilla PMX \\ prootic PRO \\ pterygoid PT \\ quadrate $\mathrm{Q}$
}

paroccipital process par. p. post-temporal fossa p.t. fos. premaxillary cavity pmx. c. sclerotic plates sc. pls. sella turcica $\mathrm{s}$ supraoccipital, surface for so supraorbital, surface for sorb vena capitis dorsalis v. cap. $d$. 

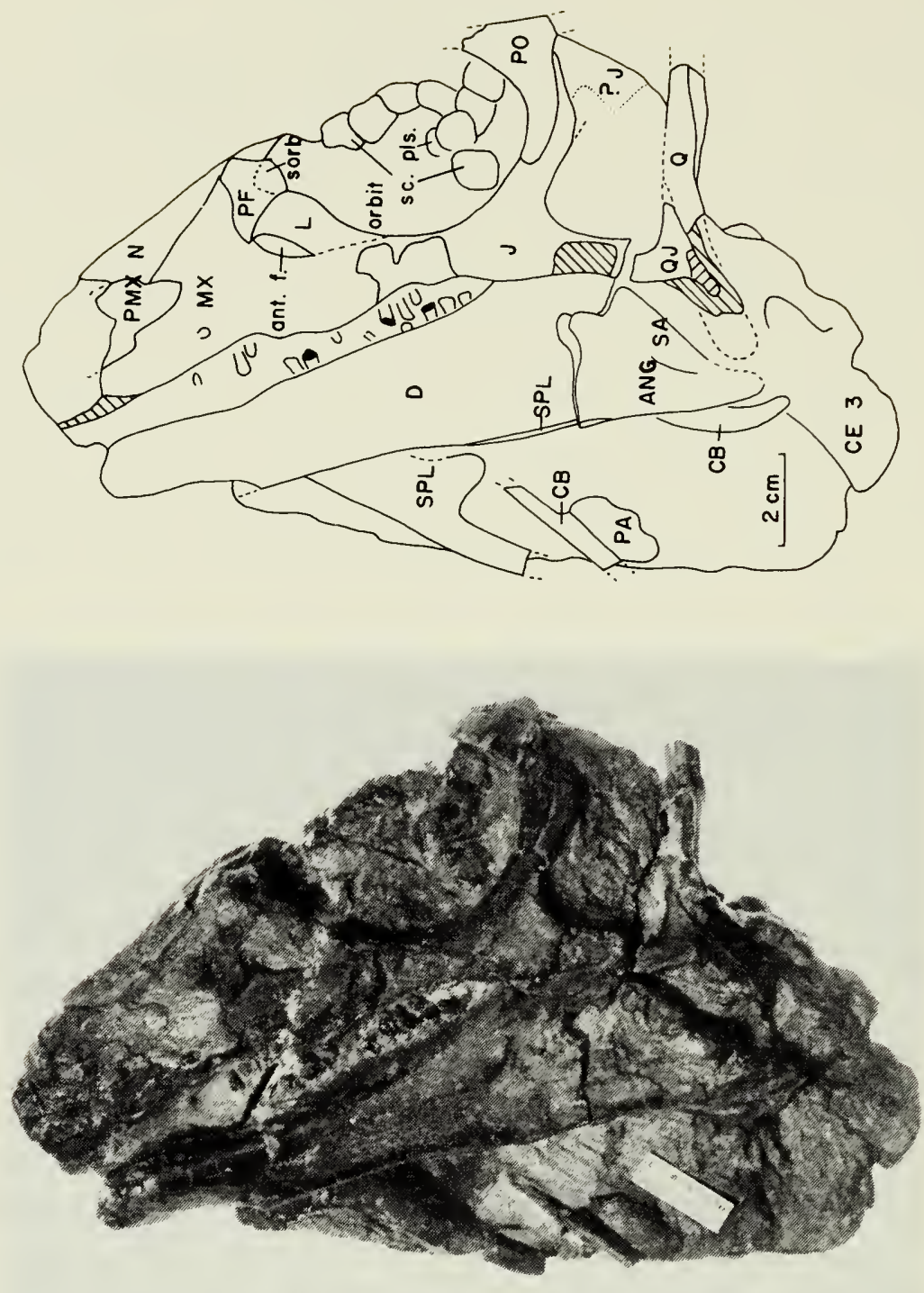

n

总范

范

\&

음

三

范

○.

焉

世志

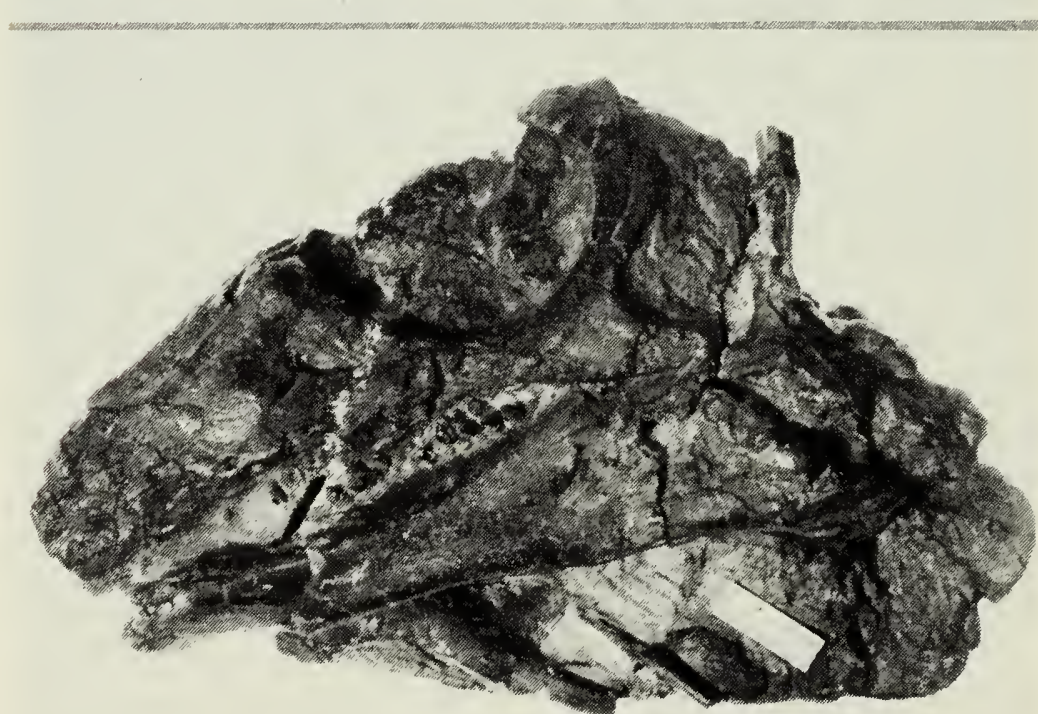

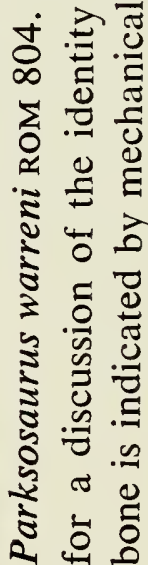

-

$\infty$ 


\section{Redescription of Parksosaurus warreni}

\section{Skull}

Bones on the left side (Fig. 1), naturally articulated, were described by Parks (1926). Those of the right side are displaced (Fig. 2), and most of the lateral wall of the skull has been removed. The medial surface of the left wall of the braincase is visible (Fig. 2) near the floor of the braincase (Fig. 2), the dorsal surface of which is exposed. A fracture in the block enables certain other structures to be seen (Figs. 3, 4). Certain bones of the skull of Parksosaurus are described by comparison with well-preserved material of Hypsilophodon (Figs. 6-8) (Galton, in press, Br. Mus.) .

The basioccipital (BO) of Parksosaurus has a subspherical occipital condyle; laterally there is a broad sutural surface, tapering anteriorly, for the exoccipital (EO) and opisthotic (OP) bones (Fig. 2). There is no trace of the suture between the basioccipital and the basisphenoid, the dorsal surface of which curves dorsally to the posterior rim of the sella turcica as in Hypsilophodon (Fig. 7c: s). The left basipterygoid process of Parksosaurus, complete but split into two pieces, is short and resembles that of Hypsilophodon (Figs. 7B, C: bpt. p.). Each process lies close to the corresponding pterygoid (PT). Only the posterior part of the parasphenoid is visible (Fig. 2: PSP) and appears to be suboval in crosssection, with a gently convex ventral surface and a sharp dorsal edge. The greatest depth of the paraoccipital process is at midlength, tapering abruptly distally (Fig. 2: par. p.). Several foramina are visible on the medial surface of the opisthotic (OP) and prootic (PRO) bones (Fig. 2: cf. Fig. 8B). The prootic part of the wall of the internal auditory meatus (im) is visible with the fossa subarcuata (fs) as another prominent groove perpendicular to the meatus. The sutural surface for the supraoccipital (so) on either side of the fossa subarcuata and the relationship between the bones of this region are as shown for Hypsilophodon (Fig. 8). That part of the prootic of Parksosaurus visible in lateral view is similar in shape to that of Hypsilophodon (Fig. 8A: PRO). The medial surface of the left orbitosphenoid of Parksosaurus is probably represented by a thin sheet of bone in the vicinity of the parasphenoid (Fig. 2: OSP, PSP), but it could as well be the lateral surface of the right orbitosphenoid. The posteroventral ramus of the orbitosphenoid is complete, but the anteroventral ramus is not. Gilmore (1909) mentioned an ossified orbitosphenoid in Camptosaurus Marsh, but this element has not been found in Dysalotosaurus (Janensch, 1955) or in Hypsilophodon. A slender rod of bone (Fig. 2: O) probably lying against the medial surface of the lachrymal in life as does a similar element in Hypsilophodon (Fig. 7B: O) may represent part of the prefrontal; in the prosauropod dinosaur Plateosaurus (AMNH 6810) a slender process of the prefrontal is medial to the lachrymal.

The anterior end of the premaxilla of Parksosaurus is absent (Figs. 1, 5: PMX), so it cannot be determined whether the premaxilla bore teeth. The posterior process of the premaxilla is broad (Figs. 1, 5). The maxilla is large, with a long suture with the nasal (Figs. 1, 5: MX, N). The small 

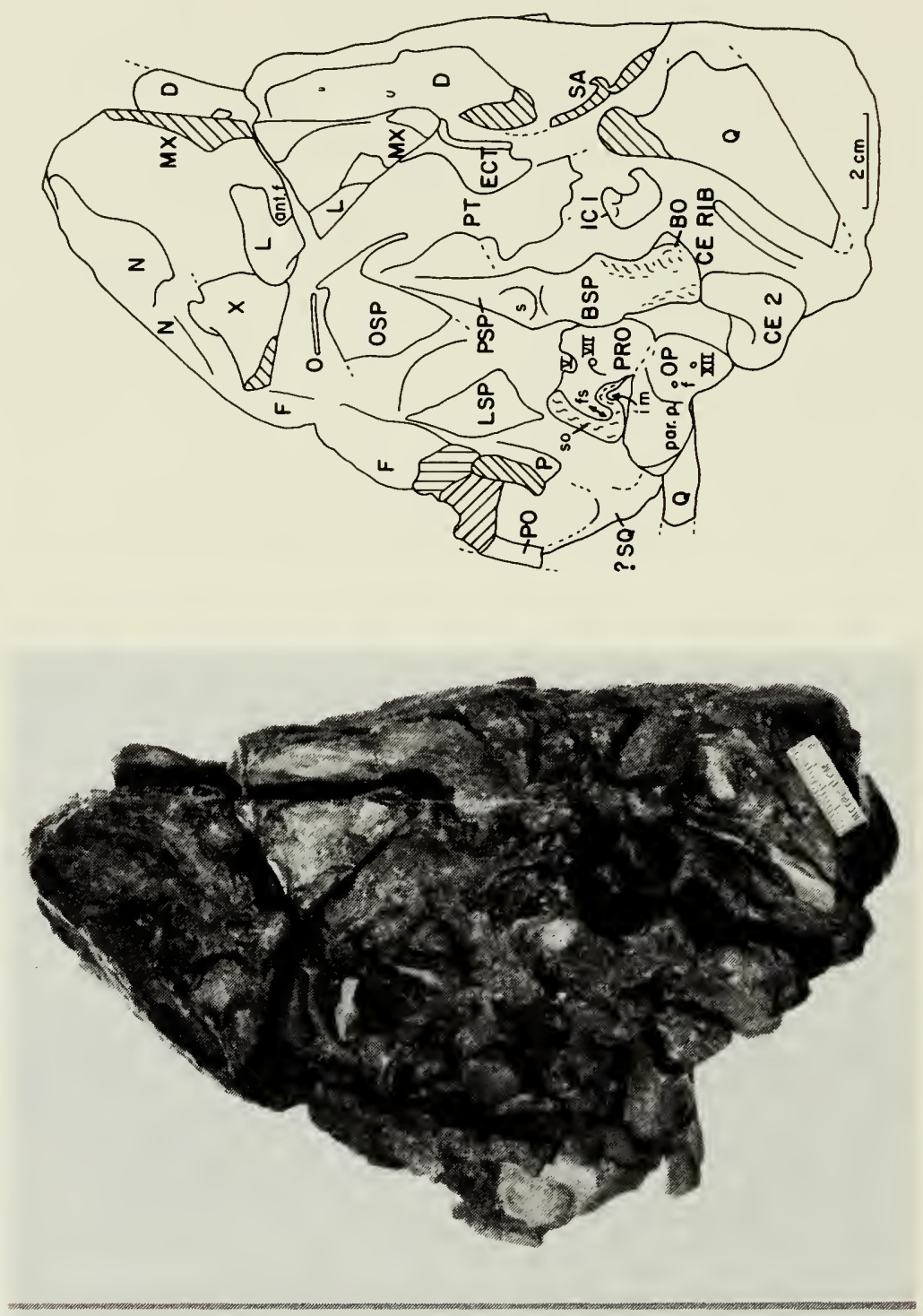

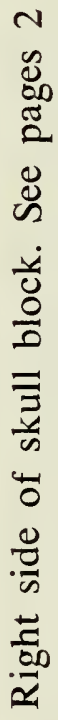

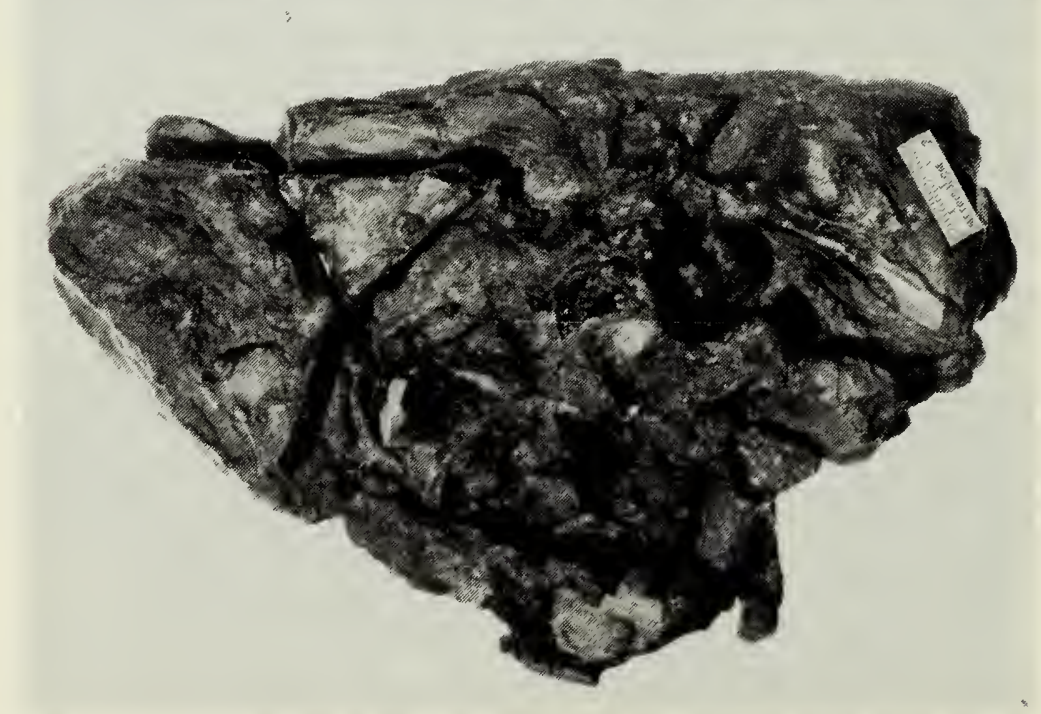

$\stackrel{+}{Ð}$

通

况

는

ま

ำ

इ

ก

ป

$N$

is 

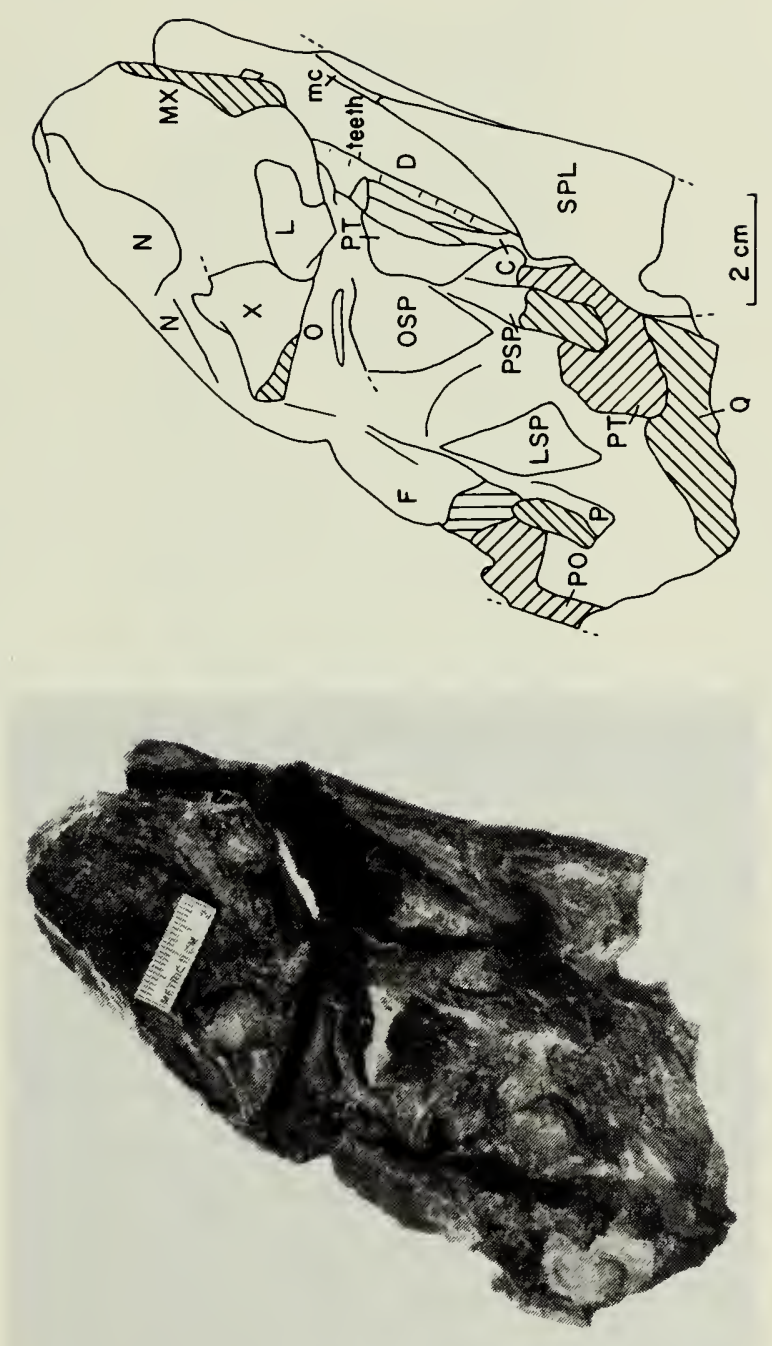

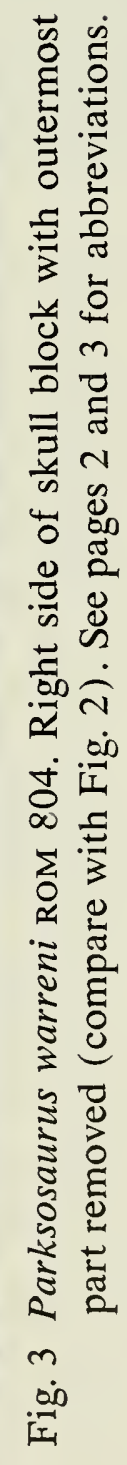



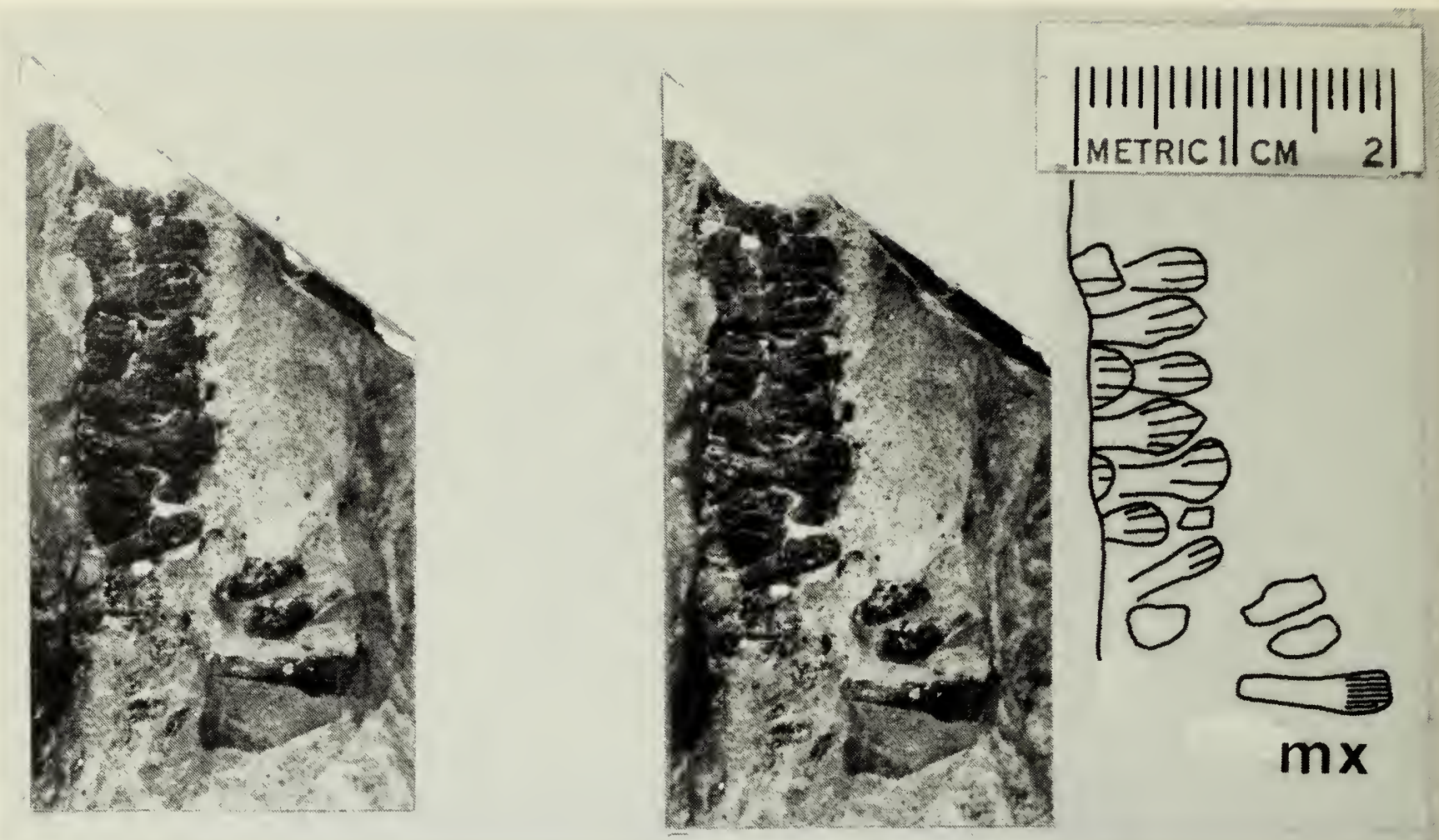

Fig. 4 Parksosaurus warreni ROM 804. Medial view of right dentary showing teeth. An isolated maxillary tooth in lateral view is indicated by " $\mathrm{mx}$ ".

remnant of the antorbital fenestra bounded by the maxilla and lachrymal (Figs. 1, 5: ant. f., MX, L) was identified as the lachrymal fenestra by Parks (1926). The suture between the maxilla and the jugal is not visible, as this region is damaged (Fig. 1: MX, J).

Most of the dorsal part of the nasal is represented only by an impression (Fig. 1: N), but posteriorly the part covered by the prefrontal (PF) is preserved. The prefrontal extends about $5 \mathrm{~mm}$ along the dorsal margin of the orbit (Fig. 5: PF). A rugose area of bone occurs on the orbital corner of the prefrontal (Fig. 1: sorb cf. Fig. 7A: SOB), probably for contact with the supraorbital (Figs. 5,6), a bone that is present in all other lower ornithopods known from adequate skull material. The right anterolateral part of the parietal is preserved (Figs. 2, 3: P), so the frontal, about the same length as the nasal (Fig. 5B: N), occupies most of the missing part of the orbital rim as in other ornithopods rather than sharing it equally with the parietal as Parks (1926) thought. The suture shown by Parks (1926, pl. 1) between the lachrymal and the maxilla is a break in the block (Fig. 1: photograph), but a horizontal suture is indicated (Figs. 1, 5A: L, MX). Part of this suture is also visible on the right side, where the lachrymal extends anterior to the antorbital fenestra (Fig. 2: ant. f.). This portion of the lachrymal is covered by the descending flange of the prefrontal and by the maxilla (Fig. 1: L, PF, MX). Dorsal to the right lachrymal is a thin bone (Fig. 2: X) that is incomplete ventrally but broadens dorsally. The bone is asymmetrical and, from its position as preserved, should be part of either the prefrontal or the nasal. But it is more likely a palpebral osteoderm or part of the medial bony sheet of the right maxilla that has separated from the rest of the bone. 

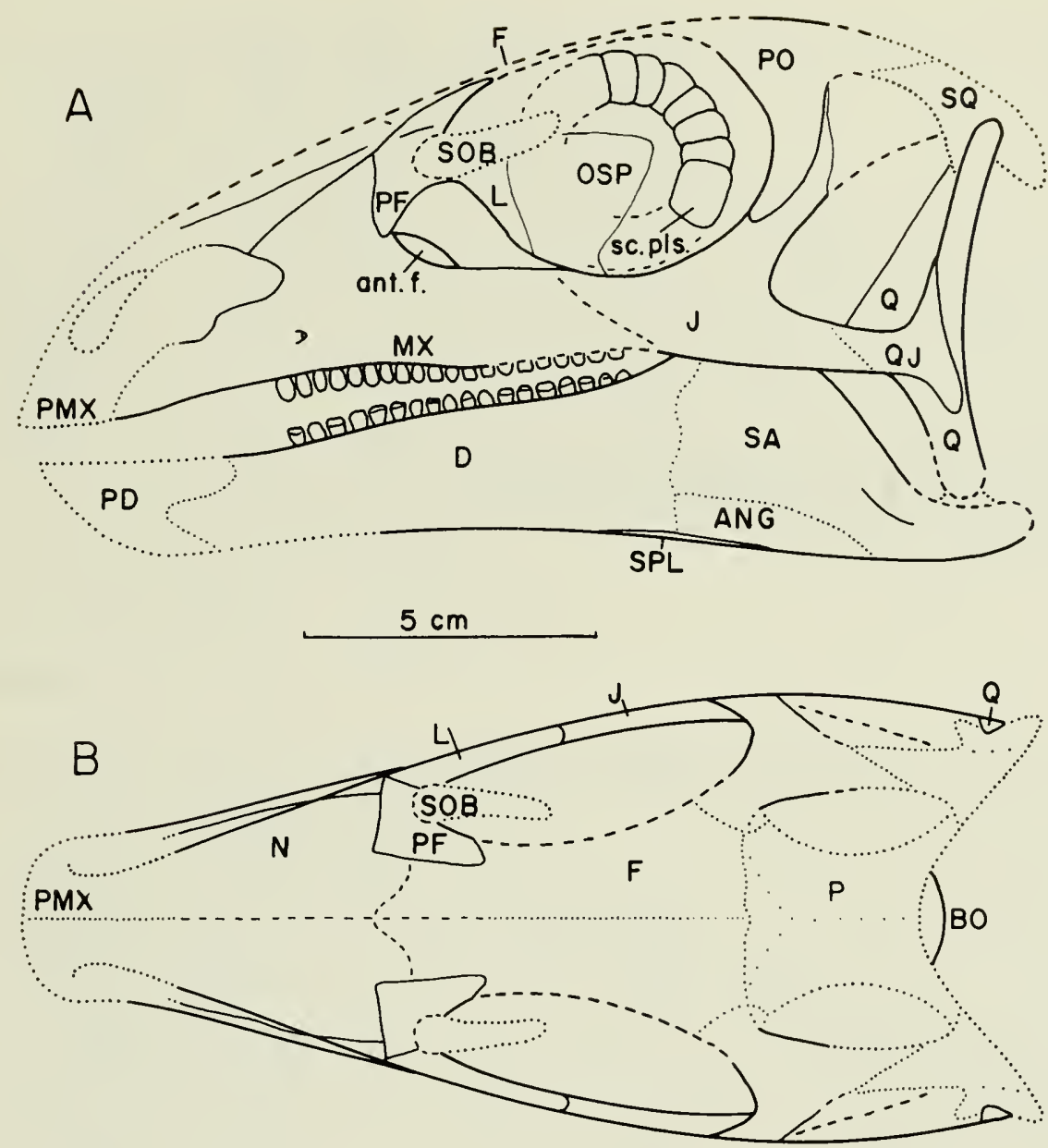

Fig. 5 Parksosaurus warreni RoM 804. Reconstruction of the skull. A. lateral view. B. dorsal view. See pages 2 and 3 for abbreviations. Evidence from ROM 804 indicated by--- - - ; hypothetical reconstruction indicated by

The dorsal part of the postorbital ( $\mathrm{PO}=$ postfrontal of Parks, 1926) is round, and in life the upper temporal fenestra probably extended to the level of the frontoparietal suture (Fig. 5в: F, P) as in Hypsilophodon (Fig. $6 \mathrm{~B})$. The dorsal process of the jugal ( $\mathrm{J}$ ) of Parksosaurus is long, and most of the bone was covered by the postorbital (PO) (Fig. 1) as in Hypsilophodon (Figs. 6A, 7A). Posterodorsally the jugal of Parksosaurus has a long, broken edge, adjacent to which is an extensive area of smooth matrix (Fig. 1: J) that represents a natural mould of the internal surface of a bone. The bone was not the postorbital, for the ventral margin of that bone is visible dorsal to the area of the natural mould. Radiographs revealed that the region of smooth matrix was continuous with that part of the jugal represented by bone. A dorsal expansion of the jugal is unusual (it tapers in all other ornithopods) and presumably strengthened the postorbital and dorsal temporal bars. The region between the jugal and the quadratojugal is damaged, and the suture cannot be found. But I consider the piece of bone next to the quadrate to be the quadratojugal rather than the jugal (see Figs. 1, 5A: QJ, J). The dorsal and ventral processes amplify the contact of the small quadratojugal with the quadrate. 

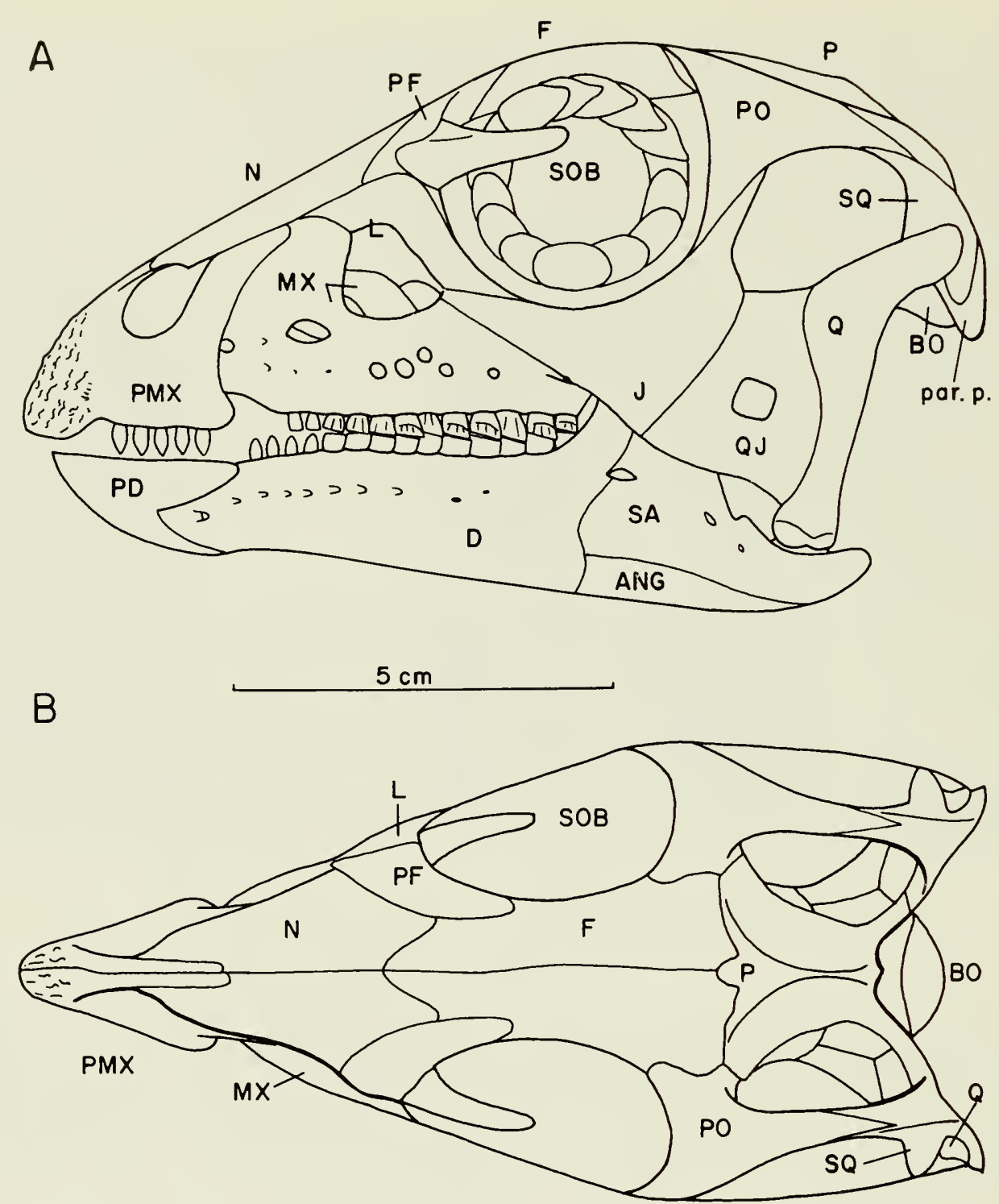

Fig. 6 Hypsilophodon foxii. Reconstruction of skull based chiefly on BMNH R197 and R2477. A. lateral view; B. dorsal view. See pages 2 and 3 for abbreviations.

The left quadrate (Fig. 1: Q) was rotated counterclockwise about its long axis before preservation. The external ridge mentioned by Parks (1926) is the anterior edge of this bone, and the faint depression mentioned by Parks sutured against the quadratojugal. The medial surface of the pterygoid flange of the right quadrate is visible (Fig. 2: Q; the quadrate has been rotated $180^{\circ}$ about its vertical axis before preservation; see also Figs. 7, 8D). Most of the central part of the pterygoid flange is slightly concave and was probably covered by the pterygoid as in Hypsilophodon (Fig. 7A). Proximally, the shaft of the quadrate of Parksosaurus is triangular in cross-section, with a sharp posterior edge that becomes less acute distally and near the mandible becomes slightly convex. The quadrate, lacking its ventral end, is $65 \mathrm{~mm}$ long. In my opinion only a few millimeters of its total length are missing, and the length of $77 \mathrm{~mm}$ estimated by Parks (1926) may have been too long. The part of the quadrate projecting ventral to the quadratojugal was probably shorter and, judging from its position in 
Hypsilophodon (Fig. 6A) and Thescelosaurus (Sternberg, 1940, fig. 16), the adjacent part of the lower jaw was probably deeper (Fig. 5A) than that shown in Parks' restoration (1926, pl. 1).

Part of the right pterygoid of Parksosaurus is visible (Fig. 2: PT). The distal edge of the alar process for the quadrate is broken and originally was probably larger, as in Hypsilophodon (Figs. 7A, 7B, 8D). The alar process for the palatine is anterior to a constricted region and perpendicular to the quadrate process, also as in Hypsilophodon. The exact outline of the alar process for the palatine cannot be determined, and the process may include part of the palatine. Part of the ectopterygoid is preserved on the posterior angle of the maxilla (Fig. 2: ECT, MX), but its sutural relationship with other cranial elements is indeterminate.

\section{Mandible}

The preserved part of the left ramus undoubtedly includes the surangular and angular in addition to the dentary, but sutures cannot be determined (Figs. 1, 5A: SA, ANG, D). The rod-like bone next to the posteroventral part of the jaw that Parks (1926) regarded as the angular is probably part of the left ceratobranchial; part of the right ceratobranchial is also preserved (Fig. 1: CB). The well-developed convexity on the posterodorsal margin of the jaw (Fig. 1) is also present on the jaw of Hypsilophodon. In medial view the splenial of Parksosaurus (Fig. 3: SPL) is similar to that of Hypsilophodon. Ventrally the right splenial (Fig. 1: SPL) becomes thick and has a longitudinal depression that fits against the dentary. The small piece of bone posterior to the splenial may represent part of the prearticular (Fig. 1: PA).

\section{Teeth}

The anterior part of the premaxilla of Parksosaurus is missing, and whether the premaxilla bore teeth is unknown. Counts for maxillary and dentary teeth for each side were about 18 and 20, respectively, for Parksosaurus (Fig. 5A), as opposed to 10-11 and 13 in Hypsilophodon (Fig. 6A). The lateral surface of the crown of a maxillary tooth of Parksosaurus (Fig. 4: $\mathrm{mx}$ ) has low, vertical ridges (Parks, 1926, fig. 1B), and the wear surfaces of three dentary teeth are visible on the left side (Fig. 1). Each surface is flat, and a layer of enamel occurs on the lateral and medial surfaces of the crown. The wear surfaces of the maxillary teeth are not visible, but the arrangement of the teeth is similar to that in Hypsilophodon, with maxillary teeth curving medially and the dentary teeth curving laterally. The lateral surface of a dentary tooth of Parksosaurus has about 10 vertical ridges that become indistinct toward the middle of the crown (Fig. 1, second tooth from posterior end of row; Parks, 1926, fig. 1A). The apical ridge of the medial surface of the crown is not clearly differentiated from other parallel ridges because the more lateral ridges are almost equally large. The medial view (Fig. 4) of the dentary teeth of the right side reveals that tooth replacement was alternate as in Hypsilophodon (Galton, in press, Br. Mus.) and most lower tetrapods (Edmund, 1960). 

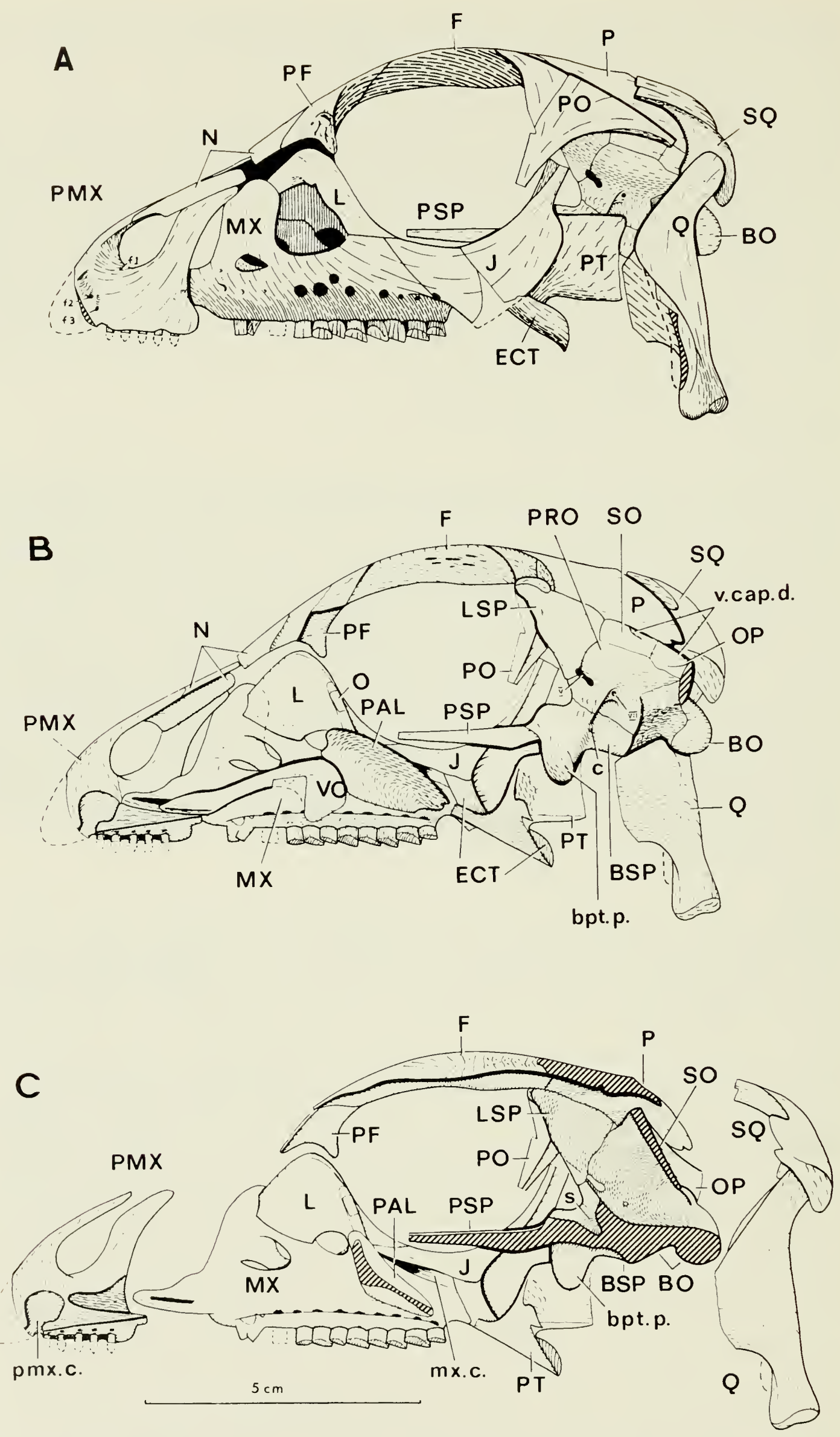

Fig. 7 Hypsilophodon foxii. Partly disarticulated skull of BMNH R2477, modified from Galton (in press, Br. Mus.). A. lateral view; B. as in A but with outer bones of left side removed; C. medial view of most of bones of right side (compare with в). See pages 2 and 3 for abbreviations. Scale $=5 \mathrm{~cm}$. 

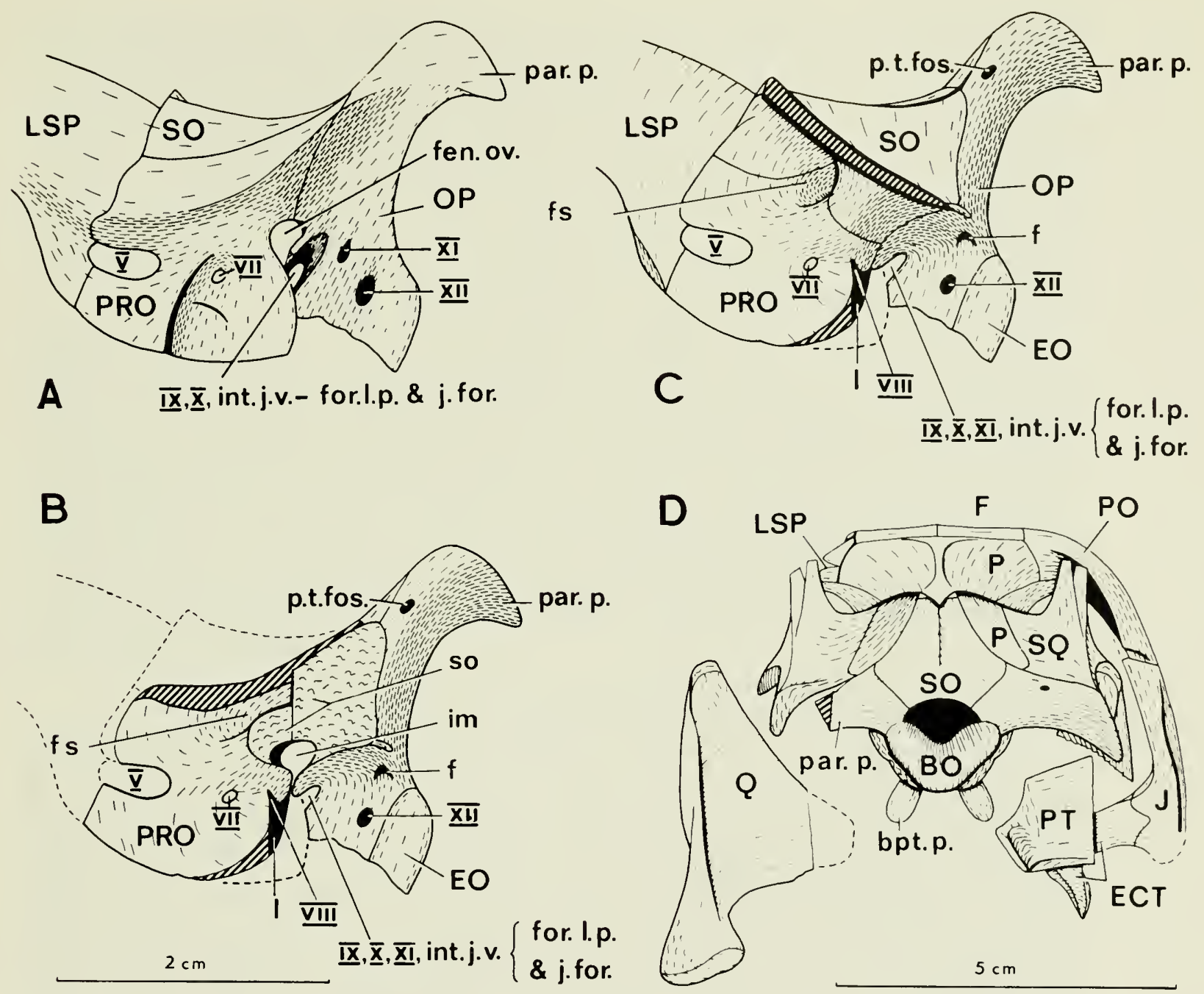

Fig. 8 Hypsilophodon foxii. Braincase, modified from Galton (in press, Br. Mus.).A-C. lateral wall of braincase, composite reconstruction: A. lateroventral view; B. mediodorsal view with laterophenoid and supraoccipital removed; C. mediodorsal view; D. occipital view of partly disarticulated skull вмNH R2477 (compare with Fig. 7).

\section{Comparisons}

With large orbits, narrow elongate frontals, and a nasal-maxillary suture, the skull of Parksosaurus (Fig. 5) resembles that of Hypsilophodon (Fig. 6). Frontals and nasals are about the same length (Fig. 5B) as in skulls of Hypsilophodon (Fig. 6B), Dryosaurus (CM 3392), and Dysalotosaurus (Janensch, 1955), whereas in Camptosaurus (Gilmore, 1909) the frontals are less than half the length of the nasals. The maximum width of the frontals is about two-thirds of their Iength (Fig. 5B: F), as in Hypsilophodon (Fig. 6в), but in Thescelosaurus (Sternberg, 1940), Dryosaurus, and Camptosaurus these distances are approximately the same.

The posterior process of the premaxilla of Parksosaurus (Figs. 1, 5A) is short, so that the maxilla contacts the nasal as in skulls of Hypsilophodon (Fig. 6A) and Fabrosaurus Ginsburg (Thulborn, 1970); but the posterior process of the premaxilla of Parksosaurus is uniquely deep. The maxilla and nasal bones are separated by the elongate, posterior process of the 
premaxilla in the skulls of Dryosaurus (CM 3392), Dysalotosaurus, and Camptosaurus. Variation in sutural contact may reflect the independent walling in of the large antorbital fenestra of thecodonts in different evolutionary lines of ornithopods. The antorbital fenestra is large in the Triassic ornithopods Fabrosaurus (Thulborn, 1970) and Heterodontosaurus Crompton and Charig (1962; Galton, 1970, fig. 4C). The size of this fenestra is variously reduced in skulls of Hypsilophodon (Fig. 6A), Dysalotosaurus, Dryosaurus, Parksosaurus (Fig. 5A), and Camptosaurus.

The dorsal end of the jugal of Parksosaurus was apparently expanded anteroposteriorly (Fig. 5A: $\mathrm{J}$ ) in a manner unique in any ornithopod. The deep, lower temporal fenestra and low jugal-quadratojugal bar (Fig. 5A: $\mathrm{J}, \mathrm{QJ})$ may be considered primitive, for this region is similar to that found in thecodonts and in the Triassic ornithischians Fabrosaurus (Thulborn, 1970) and Heterodontosaurus (Galton, 1970). The lower temporal bar is deeper in the above mentioned genera than in Camptosaurus, Dysalotosaurus, Dryosaurus, Laosaurus (Gilmore, 1925), and Hypsilophodon. The large size of the quadratojugal of Hypsilophodon (Fig. 6A: QJ) is a specialization in a genus that is primitive in most other characters.

Sternberg (1940) first noted that the crowns of the teeth of Parksosaurus and Thescelosaurus were enamelled on both sides, as they also are in Hypsilophodon. But in Parksosaurus patterns of ridging of the thickly enamelled surface of the teeth (lateral for maxillary, medial for dentary teeth), with numerous, low, rounded ridges, differ from those of any other known ornithopod. These ridges are parallel, as in Hypsilophodon and Dysalotosaurus, rather than forming two series of concentral curves, one on each side of the apical ridge, as in Thescelosaurus (Sternberg, 1940, figs. 4-8). In Thescelosaurus (NMC 8537) the thinly enamelled surfaces of the crowns of teeth have an even more prominent series of ridges than do those of the teeth of Parksosaurus. In Hypsilophodon they are barely discernible.

\section{Discussion}

Edmund (1957) discussed the function of the special foramina (one per tooth position) on the medial surface of the maxilla and dentary of hadrosaurs and ceratopsians. He concluded that the foramina were for the admission of parts of the dental lamina or for the admission of young replacement teeth produced by lamina. Edmund (1957) found no trace of these foramina on the jaws of Parksosaurus, and as foramina are absent in all other hypsilophodonts and iguanodonts, he suggested that the special foramina are associated with the development of a high alveolar wall on the lingual side. But special foramina are present in the skulls of Echinodon Owen (Thulborn, 1970, p. 430), Hypsilophodon (Fig. 7в), Dryosaurus (См 3392), Dysalotosaurus (Janensch, 1955, pl. XI, figs. 2b, 3b), Camptosaurus (YPM 1886), and Iguanodon Mantell (Hooley, 1925, figs. 2, II; 4, I). Ventral margins of foramina are visible on the lower jaw of Thescelosaurus (NMC 8537). In skulls of Hypsilophodon, Dysalotosaurus, Dryosaurus, and Iguanodon these foramina occur on the medial surface, are arranged in a 
regular line (one per tooth position), and are connected by a definite groove that was suggested by Edmund (1957) to accommodate the dental lamina. Foramina in these genera (except Iguanodon) are oval rather than circular in outline as in hadrosaurs and ceratopsians. The absence of these foramina in lower ornithopods other than Fabrosaurus probably reflects the state of preservation of the material. The region where these foramina should occur in the dentaries of Parksosaurus is badly preserved (Figs. 3, 4). The appearance of these jaws closely resembles that of one of Hypsilophodon (BMNH R196), although a series of foramina is present in other specimens of Hypsilophodon (Fig. 7c). As Edmund (1957) emphasized, the special foramina undoubtedly provided access for replacement teeth to the base of the series. The presence of these foramina in lower ornithopods represents a preadaptation for the development of a battery of teeth consisting of vertical series, for high alveolar walls may then be developed. The potential for development of dental batteries was realized independently in two lines of ornithischians, the hadrosaurs and ceratopsians, in which special foramina are the best developed.

In my opinion Sternberg (1937) was justified in establishing the genus Parksosaurus for Thescelosaurus warreni Parks. But the wear on the crown of a maxillary or dentary tooth of Thescelosaurus as two surfaces set perpendicular to each other (Sternberg, 1940, fig. 6) is peculiar to specimen NMC 8537. Wear on the two surfaces probably resulted from malocclusion, with dentary teeth occluding between rather than directly against maxillary teeth. Isolated teeth (UCMP 31815, 73086, 83000, 83001) from the Lance Formation of Wyoming, undoubtedly from Thescelosaurus, have one wear surface as in most ornithopods including Parksosaurus, and double wear facets occur on the teeth of other lower ornithopods (Galton, 1973). In addition to the differences between Thescelosaurus and Parksosaurus given by Sternberg (1940, p. 492), the frontals of Thescelosaurus (Sternberg, 1940, fig. 1) are proportionally much broader than are those of Parksosaurus (Fig. 5в: F).

Thescelosaurus parallels the earlier Camptosaurus in its graviportal adaptations. I consider that the family Iguanodontidae is polyphyletic, representing a grade that includes all graviportal ornithopods except hadrosaurs and pachycephalosaurs. Actual relationships cannot be established now, but I suggest that at least four separate evolutionary lines of hypsilophodonts became graviportal (Fig. 9). One line probably led to Camptosaurus that, as Ostrom (1970) noted, has a unique skull that is low and broad with a short, forward-inclined quadrate. A second line (lines?) led to the more typical iguanodonts such as Tenontosaurus Ostrom (1970) and Iguanodon, in which the skull is deep and narrow with an elongate, vertically-inclined quadrate. Another line that retained many hypsilophodont features led to Thescelosaurus; this locomotory transition may have occurred in the Lower Cretaceous or else Thescelosaurus was a persistently conservative iguanodont. The pachycephalosaurids were probably also derived from the hypsilophodontids (Galton, 1971c).

I characterize the family Hypsilophodontidae as follows: head small with 


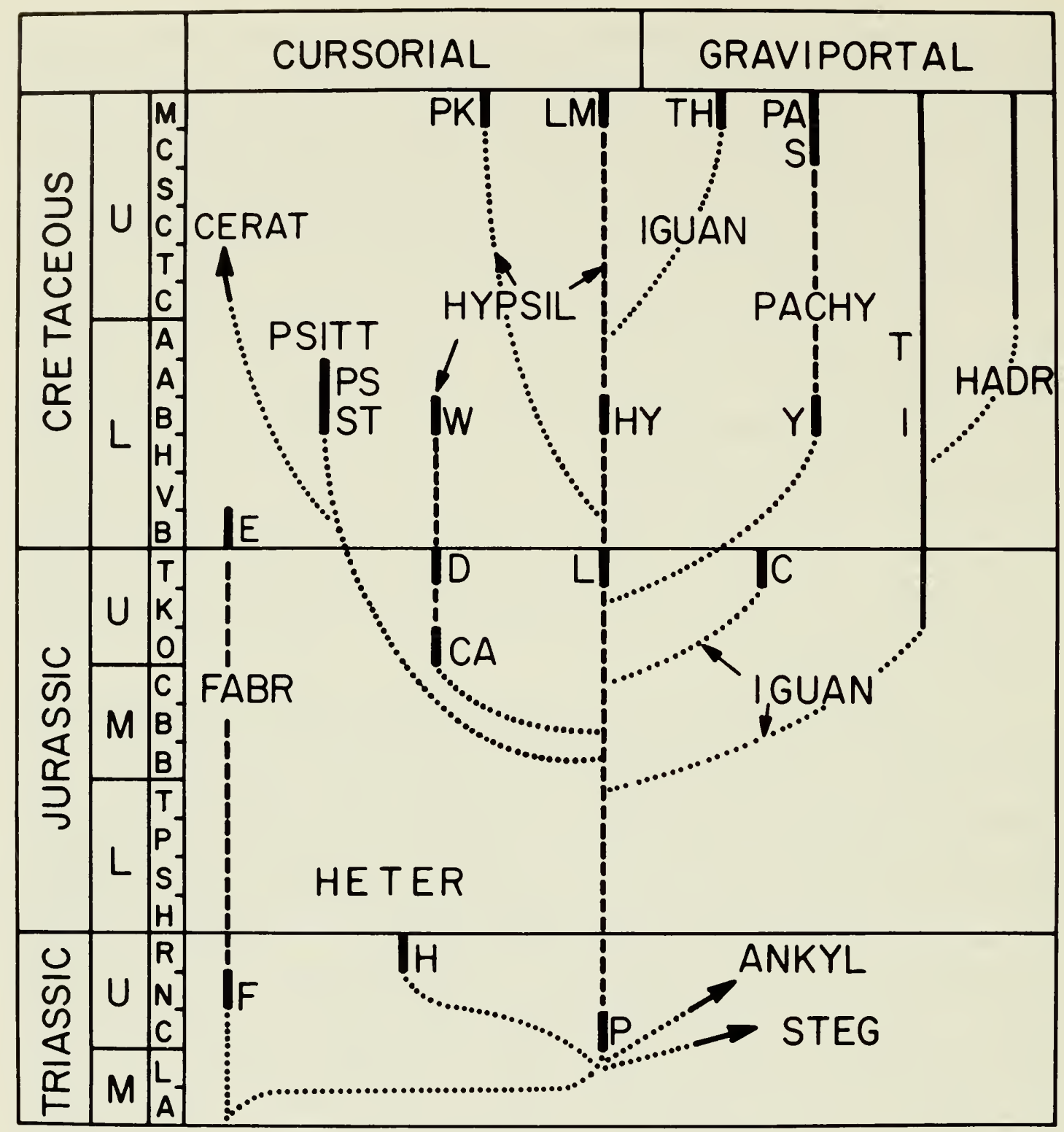

Fig. 9 Phylogeny of the Ornithopoda, from Galton (1972). Diagram to show phylogenetic relationships and the nature of the fossil record of lower ornithopods. Ages of genera are based on data in Charig (In Appleby et al. 1967), and the stratigraphic distribution is by stages, the initials of which are given in the third column.

Abbreviations: Classificationary units: ANKYL, Ankylosauria; CERAT, Ceratopsia; FABR, Fabrosauridae; HADR, Hadrosauridae; HETER, Heterodontosauridae; HYPSIL, Hypsilophodontidae; IGUAN, Iguanodontidae; PACHY, Pachycephalosauridae; PSITT, Psittacosauridae; STEG, Stegosauria. Genera: C, Camptosaurus; CA, "Camptosaurus" leedsi; D, Dryosaurus and Dysalotosaurus; E, Echinodon; F, Fabrosaurus; H, Heterodontosaurus; HY, Hypsilophodon; I, Iguanodon; L, Laosaurus; LM, "Laosaurus" minimus; P, Pisanosaurus; PA, Pachycephalosaurus; PK, Parksosaurus; PS, Psittacosaurus; S, Stegoceras; ST, Stenopelix; T, Tenontosaurus; TH, Thescelosaurus; W, Wealden hypsilophodont Galton (in press, Palaeont.); Y, Yaverlandia Galton (1971c). Actual fossil record for lower ornithopods indicated by___ no fossil record indicated by - - - --. Genera in the same vertical line are closely related, and postulated relationships are indicated by 
short snout, large orbits, no caniniform teeth or rostral beak, maxillary and dentary teeth inset (longitudinal recess to maxilla, massive dentary) with randomly formed wear surfaces not all in the same plane, cursorial with distal part of hind limb elongate. To this family I refer the following genera that are represented by adequate material: Pisanosaurus (Late Triassic); Laosaurus, Dryosaurus, Dysalotosaurus (Late Jurassic); Hypsilophodon (Early Cretaceous); and Parksosaurus (Late Cretaceous) (Galton, 1972). A comparison of the skull of CM 3392 from Utah with the holotype (YPM 1876) of Dryosaurus altus Marsh (1894) confirms the provisional identification by Gilmore (1925). Dryosaurus (сM 3392), however, does not have a supraorbital bar as was described by Gilmore (1925, fig. 3 ). The supraorbital gently tapers to a point lateral to the postorbital, and there is no sutural contact with this bone. The skull (CM 3392) of Dryosaurus altus Marsh (1894) is similar to that of Dysalotosaurus lettow-vorbecki Pompeckj (1920, p. 120) from Tanzania as described by Janensch (1955), and these two taxa may eventually prove to be congeneric, as also may Laosaurus celer Marsh (1878) and Hypsilophodon foxii Huxley (1869).

The skull of Fabrosaurus from the Upper Triassic of Lesotho is so primitive that it is probably similar to the archetypal ornithischian from which all known ornithischians can be derived (Thulborn, 1970; Galton, 1972, 1973). The skull has a flat maxilla, a slender dentary, and marginally situated maxillary and dentary teeth. Because of these uniquely primitive features (Galton, 1973), I have removed Fabrosaurus from the Hypsilophodontidae and established a separate family, the Fabrosauridae, for this genus and Echinodon (Galton, 1972). Affinities of Tatisaurus Simmons (1965) from the Upper Triassic of China and Nanosaurus Marsh (Huene and Lull, 1908) from the Upper Jurassic of North America are uncertain; it is not even certain that these genera are hypsilophodonts. Romer (1966, p. 370) listed Macelognathus Marsh from the Upper Jurassic of North America as a hypsilophodont, but Ostrom (1971) showed that it is probably a crocodile.

All hypsilophodonts were probably derived from an ancestor similar to Pisanosaurus Casamiquela (1967) from the Upper Triassic of Argentina. Dryosaurus-Dysalotosaurus, Laosaurus-Hypsilophodon, and Parksosaurus probably represent three separate lineages (Fig. 9). Femora of the Dryosaurus-Dysalotosaurus type are also found in England in the Upper Jurassic ("Camptosaurus" leedsi; Lydekker, 1889) and in the Lower Cretaceous (Wealden hypsilophodont) (Galton, in press, Palaeont.). Parksosaurus resembles the Laosaurus-Hypsilophodon line more closely than it does the Dryosaurus-Dysalotosaurus line in the elongate nature of the frontals and in the form of the femur. But the shallow lower temporal arch and extensive nasal-maxillary contact in the skull of Parksosaurus represent the retention of conservative features that are lost in Hypsilophodon.

Apart from Parksosaurus, remains of only one other taxon of the family Hypsilophodontidae have been reported from rocks of Late Cretaceous age. A partial hind limb (originally at the University of British Columbia, now NMC 9483) was described by Gilmore (1924b) as Laosaurus minimus. The 
specimen is from Southern Alberta near Burmis and was from the Blairmore Formation, the age of which was thought to be Lower Cretaceous. Allan and Rutherford (1932) concluded that the rocks concerned represented the so-called Belly River Formation, more properly the lower part of the Allison Formation (Upper Cretaceous). Russell (1949) compared the structure of Laosaurus minimus with that of other lower ornithopods and concluded that its closest affinities were with Hypsilophodon from the Lower Cretaceous of England. A fifth metatarsal is apparently absent in L. minimus (NMC 9483) but present in Hypsilophodon and Parksosaurus (Parks, 1926). The proximal end of the first metatarsal of L. minimus is slender and greatly reduced (Gilmore, 1924b, pl. 1, fig. 1). In Hypsilophodon, as in Parksosaurus (Parks, 1926, figs. 15, 16), the proximal part of the first metatarsal is robust. The cleft separating the lesser and greater trochanters of the femur of L. minimus is shallow as in Hypsilophodon and Parksosaurus. Facets on the articular surfaces of the ungual phalanges of Laosaurus minimus are symmetrical as in Hypsilophodon, rather than markedly asymmetrical as in Parksosaurus (Parks, 1926, fig. 18). Bones of the hind limb of specimen NMC 9483 are slender and obviously from a cursorial animal; as Russell (1949) noted, the bones may represent a new genus that is at the moment undefinable. Nonetheless, the specimen appears to be closely related to Parksosaurus and Hypsilophodon, and, although it could represent a new species of Hypsilophodon, it is probably best referred to as the Burmis hypsilophodontid (?Laosaurus minimus).

\section{Acknowledgments}

Most work was done at Yale University, and I thank Mr. A. Coleman for taking the photographs, Rosanne Rowen for labelling figures, Nancy Wallace (University of Bridgeport) for typing the manuscript, and the following for their comments on the paper: Drs. A. G. Edmund, C. McGowan, and L. S. Russell of the Royal Ontario Museum; D. A. Russell of the National Museum of Canada; and J. H. Ostrom of Yale University. I thank the following for the loan of material: Drs. C. Black of the Carnegie Museum; E. H. Colbert of the American Museum of Natural History; A. G. Edmund of the Royal Ontario Museum; J. H. Ostrom of Yale University; D. A. Russell of the National Museum of Canada; and S. P. Welles of the University of California at Berkeley. Radiographs of the skulls of Parksosaurus were taken by Dr. A. G. Edmund of the Royal Ontario Museum, and use of the radiographic facilities of the Laboratory of Analytical Systematics in the Royal Ontario Museum, established through a grant from the National Research Council of Canada to the Department of Zoology of the University of Toronto, is gratefully acknowledged. The manuscript was completed while I was in receipt of a Faculty Research Grant from the University of Bridgeport. 


\section{Literature Cited}

\section{ALLAN, J. A. AND R. L. RUTHERFORD}

1932 The stratigraphical horizon of Laosaurus minimus Gilmore. Am. J. Sci., ser. 5, vol. 24, no. 141, pp. 225-227.

APPLEBY, R.M., A.J. CHARIG, C.B. COX, K. A. KERMACK AND L. B. H. TARLO

1967 Reptilia. In Harland, W. B. et al., eds. The fossil record. A symposium with documentation jointly sponsored by the Geological Society of London and the Palaeontological Association. London, Geological Society of London, pp. 695-731.

CASAMIQUELA, R. M.

1967 Un nuevo dinosaurio ornitisquio triásico (Pisanosaurus mertii; Ornithopoda) de la formación Ischigualasto, Argentina. Ameghiniana, vol. 5, no. 2, pp. 47-64. [In Spanish, English summary].

CROMPTON, A. W. AND A. J. CHARIG

1962 A new ornithischian from the Upper Triassic of South Africa. Nature, vol. 196, no. 4859, pp. 1074-1077.

EDMUND, A. G.

1957 On the special foramina in the jaws of many ornithischian dinosaurs. Life Sci. Contr., R. Ont. Mus., no. 48, pp. 1-14.

1960 Tooth replacement phenomena in the lower vertebrates. Life Sci. Contr., R. Ont. Mus., no. 52, pp. 1-90.

GALTON, P. M.

1970 Ornithischian dinosaurs and the origin of birds. Evolution, vol. 24, no. 2, pp. 448-462.

1971a Hypsilophodon, the cursorial non-arboreal dinosaur. Nature, vol. 231, no. 5299, pp. 159-161.

$1971 \mathrm{~b}$ The mode of life of Hypsilophodon, the supposedly arboreal ornithopod dinosaur. Lethaia, vol. 4, no. 4, pp. 453-465.

1971c A primitive dome-headed dinosaur (Ornithischia: Pachycephalosauridae) from the Lower Cretaceous of England and the function of the dome of pachycephalosaurids. J. Paleont., vol. 45, no. 1, pp. $40-47$.

1972 Classification and evolution of ornithopod dinosaurs. Nature, vol. 239, no. 5373, pp. 464-466.

1973 On the cheeks of ornithischian dinosaurs. Lethaia, vol. 6, no. 1, pp. 67-89.

In press The ornithischian dinosaur Hypsilophodon from the Wealden of the Isle of Wight. Bull. Br. Mus. Nat. Hist., Geol.

In press A new hypsilophodontid from the Lower Cretaceous of England with comments on ornithopod dinosaurs. Palaeontology.

GILMORE, C. W.

1909 Osteology of the Jurassic reptile Camptosaurus with a revision of the species of the genus, and description of two new species. Proc. U.S. Natn. Mus., vol. 36, no. 1666, pp. 197-332.

1913 A new dinosaur from the Lance Formation of Wyoming. Smithson. Misc. Collns., vol. 61, no. 5, pp. 1-5.

1915 Osteology of Thescelosaurus, an orthopodous dinosaur from the Lance Formation of Wyoming. Proc. U.S. Nat. Mus., vol. 49, no. 2127, pp. 591-616. 
1924a On Tröodon validus, an orthopodous dinosaur from the Belly River Cretaceous of Alberta, Canada. Bull. Dep. Geol. Univ. Alberta, no. 1 , pp. 1-43.

1924b A new species of Laosaurus, an ornithischian dinosaur from the Cretaceous of Alberta. Trans. R. Soc. Can., ser. 3, vol. 18, sec. 4, pp. 1-6.

1925 Osteology of ornithopodous dinosaurs from the Dinosaur National Monument, Utah. Mem. Carneg. Mus., vol. 10, no. 4, pp. 385-410.

HOOLEY, R. W.

1925 On the skeleton of Iguanodon atherfieldensis sp. nov., from the Wealden Shales of Atherfield (Isle of Wight). Q. J. Geol. Soc. Lond., vol. 81 , pt. 1 , no. 321 , pp. 1-61.

HUENE, F. V. AND R. S. LULL

1908 Neubescheibung des Originals von Nanosaurus agilis Marsh. Neues Jb. Miner. Geol. Paläont., band 1, pp. 134-144.

HUXLEY, T. H.

1869 On Hypsilophodon, a new genus of Dinosauria. Proc. Geol. Soc., no. 204, pp. 3-4 [Abstract].

JANENSCH, W.

1955 Der Ornithopod Dysalotosaurus der Tendaguruschichten. Palaeontographica Suppl., band 7, tiel 3, lief 3, pp. 105-176.

LYDEKKER, R.

1889 On the remains and affinities of five genera of Mesozoic reptiles. Q. J. Geol. Soc. Lond., vol. 45, pt. 1, no. 177, pp. 41-59.

MARSH, O. C.

1878 Notice of new dinosaurian reptiles. Am. J. Sci., ser. 3, vol. 15, no. 87, pp. 241-244.

1894 The typical Ornithopoda of the American Jurassic. Am. J. Sci., ser. 3, vol. 48 , no. 283 , pp. $85-90$.

OSTROM, J. H.

1970 Stratigraphy and paleontology of the Cloverly Formation (Lower Cretaceous) of the Bighorn Basin area, Wyoming and Montana. Bull. Peabody Mus. Nat. Hist., no. 35, pp. 1-234.

1971 On the systematic position of Macelognathus vagans. Postilla, no. 153, pp. 1-10.

PARKS, W.A.

1926 Thescelosaurus warreni, a new species of orthopodous dinosaur from the Edmonton Formation of Alberta. Univ. Toronto Stud. Geol. Ser., no. 21, pp. 1-42.

POMPECKJ, J. F.

1920 Das angebliche Vorkommen und Wandern des Parietal foramens bei dinosauriern. Sber. Ges. Naturf. Freunde Berl. 1920, pp. 109-129. 
ROMER, A. S.

1966 Vertebrate paleontology (3d ed.). Chicago, University of Chicago Press. 468 pp.

RUSSELL, L. S.

1949 The relationships of the Alberta Cretaceous dinosaur "Laosaurus" minimus Gilmore. J. Paleont., vol. 23, no. 5, pp. 518-520.

SIMMONS, D.J.

1965 The non-therapsid reptiles of the Lufeng Basin, Yunnan, China. Fieldiana, Geol., vol. 15, no. 1, pp. 1-93.

STERNBERG, C.M.

1937 A classification of Thescelosaurus, with a description of a new species. Proc. Geol. Soc. Am. 1936, pp. 375 [Abstract].

1940 Thescelosaurus edmontonensis, n. sp., and the classification of the Hypsilophodontidae. J. Paleont., vol. 4, no. 5, pp. 481-494.

THULBORN, R. A.

1970 The skull of Fabrosaurus australis, a Triassic ornithischian dinosaur. Palaeontology, vol. 13, pt. 3, pp. 414-432. 

